\title{
What Does the Slave Trade in the Saqaliba Tell Us about Early Islamic Slavery? MAREK JANKOWIAK
}

Faculty of History, University of Oxford, Oxford, UK; e-mail: marek.jankowiak@orinst.ox.ac.uk doi:10.1017/S0020743816001240

The Saqaliba - a term that in medieval Arabic literature denoted the Slavic populations of central and eastern Europe (and possibly some of their neighbors) ${ }^{1}$ —offer a particularly insightful case study of the mechanisms of the early Islamic slave trade and the nature of the Muslim demand for slaves. What makes them such an ideal case study is their high visibility in texts produced in the Islamic world between the early 9th and early 11 th centuries. Arab geographers and diplomats investigated their origins, while archaeological material, primarily hundreds of thousands of dirhams found in Scandinavia and the Slavic lands, contains traces of the trade in them. By combining these strands of evidence, we can build an exceptionally detailed image of slave trade systems that supplied Saqaliba to the Islamic markets, which, in turn, can be used to illustrate more general mechanisms governing the trade in and demand for slaves in the medieval Islamic world.

In textual sources, the Saqaliba appear mostly in palatial contexts: men filled the ranks of the guards of the Abbasid, Fatimid, and Umayyad caliphs; women and eunuchs populated their harems, with eunuchs also employed in the dīwanns. ${ }^{2}$ These sources focus on palatine slavery and offer a glimpse of private ownership of Saqaliba slaves only in exceptional circumstances, such as the presence of a dozen of Saqlabi eunuchs in the inventory of the household of a rich governor. ${ }^{3}$ Private demand existed-numerous anecdotes featuring Saqaliba slaves in the works of al-Jahiz suggest that their presence was banal in 9th-century Basra ${ }^{4}$ - but the palaces of caliphs and amirs were no doubt the largest source of demand for Saqaliba concubines, eunuchs, bureaucrats, and guards.

The presence of Saqaliba slaves in Islamic palaces and cities aroused the curiosity of Arab geographers and diplomats. The former left ethnographic descriptions of northern and eastern Europe that allow us to identify the Saqaliba as Slavs. ${ }^{5}$ The latter explored the markets where Muslim merchants acquired captives from northern warriors, such as Bulgar on the Volga where in 921-22 Ahmad b. Fadlan observed the exchange of Saqaliba slave girls brought by Rus (i.e., Scandinavian) merchants for Islamic coins and beads, which were offered by a caravan from Khorezm, or Prague, visited forty years later by Ibrahim b. Ya ${ }^{c} q u b$, probably a merchant from al-Andalus. ${ }^{6}$

Although in many respects similar, the two markets looked in different directionsPrague toward al-Andalus, and Bulgar toward Khorezm and the Samanid emirate in Central Asia-and functioned according to different principles. Whereas in Bulgar Scandinavian merchants demanded high-quality silver supplied by the Samanids from their abundant mines in Central Asia in exchange for the captives, it is less clear how slaves were paid for in Prague. In the absence of coins or any other objects of Spanish origin in Central Europe, perishable goods such as textiles are a best guess.

A lack of numismatic material precludes a precise reconstruction of the chronology of the Prague market, but there is little doubt that the period of its prosperity, from the early 10th to the early 11 th century, coincided with the period of centralization of the 
Umayyad caliphate, achieved with the help of slave troops composed to a significant extent of Saqaliba. ${ }^{7}$ The collapse of central power in al-Andalus in the early 11 th century spelled the end of the demand for Saqaliba and, consequently, the end of the Spanish trade with central Europe. In 10th-century al-Andalus as in 9th-century Iraq, Saqaliba slaves were sought, it would seem, primarily by the palace.

The staggering quantities of Abbasid and Samanid dirhams found in Scandinavia and the Slavic lands give a clearer idea of the dynamics of Iraq and Central Asia's trade with northern Europe. A conservative estimate puts their number at 400,000, which is no doubt but a small fraction of the total inflow. ${ }^{8}$ The geographical distribution of dirham hoards, in connection with archaeological traces of depopulation, points to the stretch of Slavic lands from the Elbe to the Russian rivers as the place of origin of the Saqaliba sold to the Islamic world. ${ }^{9}$ Their chronology, in contrast, allows us to reconstruct the fluctuations of the trade, which can be summarized in two phases: in the 9th century dirhams flowed northwards from Iraq via Khazaria, whereas after the year 900 the main trade route shifted eastwards, to Samanid central Asia and the market of Bulgar.

The earlier phase coincides with mentions of the Saqaliba in literature related to palatial contexts in Iraq; it is therefore tempting to relate their importation to the demand emanating from the caliphal court, and to identify political upheaval in Samarra and Baghdad as one of the reasons for the cessation of the flow of Abbasid dirhams northwards and the concomitant disruption of the slave trade in the late 860s.

The 10th-century phase is more ambiguous: it is difficult to reconcile the abundance of Samanid coinage in northern European hoards with the absolute silence on the Saqaliba in textual sources produced in Central Asia. Numerous sources show, for instance, that the guard of the amirs was constituted of Turkic, not Saqaliba, mamluks. The reason why Saqaliba slaves found themselves below the radar of courtly literature is suggested by the account of Ibn Fadlan. He identifies private merchants from Khorezm as the main agents of trade with Bulgar, a view shared by Arab geographers who depict Khorezm as an entrepôt for wares imported from afar, such as slaves and furs. ${ }^{10}$ The Saqaliba, then, were probably distributed through capillary trade networks largely invisible in the sources. A rare contemporary glimpse of their workings, related to the 10th-century slave trade even if not specifically to the Saqaliba, is offered by the Pandnamah of Sebüktegin, the founder of the Ghaznavid dynasty. In this purportedly autobiographical account, Sebüktegin tells the story of his kidnapping by a rival Turkish clan and subsequent sale to a merchant from Chach, who provided for his military training and eventually sold him to the Samanid generalissimo Alptigin, himself a former slave. ${ }^{11}$ We can surmise that many slaves were similarly distributed to the households of court officials and urban elites. But although privately run, the Khorezmian slave trade still relied on the state in one crucial regard: the supply of silver, the commodity most demanded by the Scandinavians. When the quality of Samanid dirhams declined in the 950s, possibly as a result of the dwindling supply of silver, the trade system quickly collapsed.

The example of the Saqaliba illustrates the complexities of the early Islamic slave trade. The extension of the trade routes, the unpredictable politics of the steppe and forest zones, the necessity of providing payment in the form required by trade partners, and above all the variations in Islamic demand made this long-distance slave trade system inherently unstable. None of its three main phases - the Abbasid, the Samanid, and the Spanish Umayyad - lasted for more than a century. Moreover, the scale of the trade—in 
the thousands of slaves per year, judging from the quantities of dirhams found in northern Europe - the distances involved, and the fact that trade was carried out overland required sophisticated logistics and organization. Large caravans, such as the one joined by Ibn Fadlan that is said to have counted 5,000 men even before the slaves were purchased, ${ }^{12}$ no doubt dealt with such problems as feeding and guarding vast numbers of people efficiently.

Similar mechanisms must have been at work in other long-distance overland trade systems, especially the trans-Saharan, although the scarcity of sources for the early Islamic period prevents us from appreciating its geographical and chronological fluctuations. Maritime slave trade, such as that conducted by Persian sailors from Siraf, ${ }^{13}$ allowed more flexibility: logistic challenges were smaller and the resilience of the system greater thanks to a broader range of traded goods.

We can perhaps see long-distance slave trade systems, with their complex logistics and immanent incertitude, as a special case rather than a pattern for the Islamic slave trade. Frontier trade and warfare all along the borders of the Islamic world appear to have been sufficient to satisfy the urban demand for domestic and sexual slaves. The diversity of these slaves' geographical origins is illustrated by the mid-11th-century guidebook to purchasing slaves composed by Ibn Butlan, which listed more than twenty places of origin. With the exception of Zanj and Saqaliba supplied by long-distance trade systems, almost all of the slaves had been situated within or just outside the borders of the Islamic world. ${ }^{14}$

Whenever additional supplies of slaves from afar were available, Islamic slavery expanded to new areas of life. The large numbers of captives shipped from the northern Mediterranean and from eastern Africa in the 9th and 10th centuries, for example, probably resulted in the exceptional regimes of agricultural slavery in Ifriqiya and lower Iraq. ${ }^{15}$ There is no hint of Slavic slaves being used in agriculture, but their appearance on the market encouraged, at least in al-Andalus, the formation of a mamluk army that was instrumental in the consolidation of central political power. Such developments were, however, short-lived and did not outlast the unstable trade systems.

The reliance of Islamic slavery on trade, and the resulting emergence of complex long-distance slave trade systems such as the one described earlier, was due to a fundamental characteristic of Islamic slavery: the low rate of natural reproduction. The control of masters over female slaves and the relative ease of manumission-considered a meritorious act in the Qur'an (e.g., 2:177, 90:13) and meticulously regulated by Islamic law $^{16}$ - meant that reproduction was less integral to maintaining the slave population than in other slave systems. In early imperial Rome, for instance, the biological replacement rate of the slave population has been estimated at as high as 80 percent, with the external supply only filling the gap resulting from the low fertility of the slaves and manumission. ${ }^{17}$ Early Islamic slavery was governed by an opposite logic: in the absence of multigenerational slavery, the slave population needed to be constantly replenished. This resulted in an unusual prominence of external sources of slaves, accessed through warfare, raiding, and trade.

As opposed to, for instance, 10th-century Byzantium, which had access to significant pools of slaves and captives but did not find much use for them within its social and political structures, ${ }^{18}$ in the early Islamic world the demand for slaves was rarely met by adequate supply. Consequently, the economic and, with the exception of palatine slavery, 
political role of slavery remained limited. Such was also the case with the Saqaliba. Once they appeared in the Islamic world as a result of a mutually profitable barter with the silver-seeking Scandinavians, a variety of uses was found for them: they became exotic luxury slaves in the palaces of Baghdad and perhaps in the urban households of Central Asia, mamluk soldiers in the Muslim West, and eunuchs everywhere. But Islamic sources took no note of the cessation of their importation around the year 1000: the Islamic world seamlessly turned to other sources of slaves or learned to live with a smaller number of them.

\section{NOTES}

${ }^{1}$ David Ayalon, Eunuchs, Caliphs and Sultans: A Study in Power Relationships (Jerusalem: Magnes Press, Hebrew University, 1999), 349-52, convincingly argues against the view that Saqaliba was a generic term for northern Europeans. See also P. Guichard and Mohamed Meouak, "al-Sakaliba," in Encyclopaedia of Islam, 2nd ed., ed. C. E. Bosworth et al. (Leiden: Brill, 1995), 8:879-81.

${ }^{2}$ For a useful collection of references to the Saqaliba in the Islamic sources, see D.E. Mishin, Sakaliba (slaviane) v islamskom mire v rannee srednevekov'e (Moscow: IV RAN, "Kraft+," 2002).

${ }^{3}$ Yaqut, Kitab Mu'jam al-Buldan, ed. Ferdinand Wüstenfeld, vol. 2 (Leipzig: In Commission bei F. A. Brockhaus, 1867), 618.

${ }^{4}$ See al-Jahiz, Kitab al-Hayawan, ed. 'Abd al-Salam Muhammad Harun (Misr, 1966-69), 1:116-18; and passages collected in Tadeusz Lewicki, Źródta arabskie do dziejów Stowiańszczyzny (Wrocław: Zakład imienia Ossolińskich, 1956), 1:159-74.

${ }^{5}$ See, for example, Mas'udi, Les prairies d'or, trans. C. Barbier de Meynard, A. Pavet de Courteille, and C. Pellat (Paris: Société asiatique, 1962), 1:§§ 905-9.

${ }^{6}$ Paul Lunde and Caroline Stone, Ibn Fadlan and the Land of Darkness: Arab Travellers in the Far North (London: Penguin, 2012).

${ }^{7}$ Mohamed Meouak, Saqaliba, eunuques et esclaves à la conquête du pouvoir: géographie et histoire des élites politiques "marginales" dans l'Espagne umayyade (Helsinki: Academia Scientiarum Fennica, 2004).

${ }^{8}$ Roman K. Kovalev and Alexis C. Kaelin, "Circulation of Arab Silver in Medieval Afro-Eurasia: Preliminary Observations," History Compass 5 (2007): 563.

${ }^{9}$ See the studies collected in Archaeology of Early Medieval Slavery (provisional title), ed. Felix Biermann and Marek Jankowiak (forthcoming).

${ }^{10}$ Ibn Hawqal, Configuration de la terre (Kitab Surat al-Ard), trans. J.H. Kramers and G. Wiet (Beyrouth: Commission internationale pour la traduction des chefs-d'œuvre, 1964), 2:463.

${ }^{11}$ M. Nazim, "The Pand-Namah of Subuktigin," Journal of the Royal Asiatic Society of Great Britain and Ireland (1933): 605-28.

${ }^{12}$ Ibn Fadlan, Two Arabic Travel Books: Accounts of China and India, trans. James E. Montgomery (New York: New York University Press, 2014), 207.

${ }^{13}$ Buzurg ibn Shahriyar, The Book of the Wonders of India: Mainland, Sea and Islands, trans. G. S. P. Freeman-Grenville (London: East-West, 1981).

${ }^{14}$ See Hans Müller, Die Kunst des Sklavenkaufs, nach arabischen, persischen und türkischen Ratgebern vom 10. bis zum 18. Jahrhundert (Freiburg: Klaus Schwarz Verlag, 1980), 50-80.

${ }^{15}$ Mohamed Talbi, "Law and Economy in Ifriqiya (Tunisia) in the Third Islamic Century: Agriculture and the Role of Slaves in the Country's Economy," in The Islamic Middle East, 700-1900: Studies in Economic and Social History, ed. Abraham L. Udovitch (Princeton, N.J.: Darwin Press, 1981), 209-50; Alexandre Popović, La révolte des esclaves en Iraq au IIIe, IXe siècle (Paris: P. Geuthner, 1976).

${ }^{16}$ See Jonathan E. Brockopp, Early Maliki Law: Ibn 'Abd al-Hakam and His Major Compendium of Jurisprudence (Leiden: Brill, 2000), 147-58, 162-205.

${ }^{17}$ Walter Scheidel, "The Roman Slave Supply," in The Cambridge World History of Slavery, vol. 1, The Ancient Mediterranean World, ed. Keith Bradley and Paul Cartledge (Cambridge: Cambridge University Press, 2011), 306-8.

${ }^{18}$ See in general Youval Rotman, Byzantine Slavery and the Mediterranean World (Cambridge, Mass.: Harvard University Press, 2009). 